\title{
The Epistemological Foundations of ReAChing QuRb (Proximity) in SAHIFA SAJJADIYYa
}

\author{
Mohammad Ali Niyazi \\ Faculty of Philosophy, Al-Mustafa International University, \\ Qom, I. R. Iran
}

\begin{abstract}
As the Divine Nearness should be accomplished and grasped, its elements and obstacles should be known and used. The enlightening sayings of Infallible Figures are the most reliable source for reaching the Divine Nearness. In this research on Sahifa Sajjadiyya, we will analyze these elements. Using the great treasure of Infallible Figures' Supplications and Duas, we put forward the cognitive elements like Tawakkul, Khawf, and Raja and other elements which are the cause of the Divine Nearness. So, referring to Sahifa Sajjadiyya, we glance at the most important elements of the Divine Nearness.
\end{abstract}

Keywords: Islam, proximity, prayer, spiritual supplications, Sahifa

\section{Terminology of Nearness (Qurb)}

First, we have to clarify literal and terminological meanings and usages of the word "Qurb" and to know what it means.

\section{Literal Definition}

There are several meanings and uses for the word "Qurb" in dictionaries mentioned by experts:

Ibn Manzur said it means dunuw / being near, as used in Arabic: qarrabtuhu taqriban - ay adnaytuhu / I made it near (Ibn Manzur 1997, word qurb).

Corresponding author: niyazi1358@yahoo.com 
Raghib also said that the meaning of "Qurb" is in contrast with the word "Bu'd/far". He also counted several types of "Qurb" like spatial, temporal, relative, position and stage, observance, and the meaning of comprising of power. This point is useful in applying these usages with the observed meaning of "Qurb" in the relationship between God and Servants. (Raghib Esfihani 1992, word qurb).

1. Spatial Nearness: "but do not approach this tree, lest you should be among the wrongdoers" (Quran 2: 35).

2. Temporal Nearness: "Mankind's reckoning has drawn near to them" [21: 1]; "The Hour has drawn near and the moon is split" (54:1).

3. Relative Nearness: "relatives and orphans" (2: 83); "Men have a share in the heritage left by parents and near relatives" (4: 7).

4. Nearness in position and stage: "And the Foremost Ones are the foremost ones. they are the ones brought near [to Allah]" (56: 10-11); "nor would the angels brought near [to Him]" (4: 172); "Of course; and you will be among members of my inner circle" (26: 42).

5. Nearness in Observance: "indeed Allah's mercy is close to the virtuous" (7: 56).

6. Comprising of Power: "and We are nearer to him than his jugular vein" (50: 15).

Among these meanings, the $4^{\text {th }}$ meaning of "Qurb" is our intended one. So, when we talk about the Divine Nearness which is the human ultimate desire and which humans should move toward with their own intention and will, we don't mean temporal or spatial nearness. Because God is the creator of time and space as they are under His sovereignty and no spatiotemporal thing has any relation with Him.

\section{Terminological Definition}

The terminological meaning (in accordance with the relationship between God and servants) is taken from its literal meaning i.e. what is mentioned by Raghib about "nearness in position and stage". So, the "Muqarrabin or Muqarrabun" are those who are at the high stage and position and have reached the stage of "Nearness to God".

It is clear that "Nearness to God" does not mean spatial and temporal proximity, because Almighty God is not a material entity. The other mentioned meanings of "Qurb" like conventional and nearness are not appropriate with Almighty God, but rather here we have an existential reality i.e. as Almighty God is the Absolute Perfection, the nearness in regards 
to such a thing is being more perfect i.e. human existential extension as a human being grasps Divine oriented existence with performing Godwilled things.

\section{An Analysis of Imamate Cognition}

Pondering on the Quran, which is the book of human guidance and healing, the right book in which no falsehood is possible, the accepted book of all Muslim sects, and the most authentic source for Imamate cognition, we analyse this point.

\section{A) Imam Ali said about the significance of Imam:}

"Just see the Household of Holy Prophet, go where they are, follow them, because they never ever misguide you and don't lead you astray. If they stand and don't like to do anything, do such way, and if they move on, go ahead but don't put them back, elsewhere you became deviant, and don't remain back, elsewhere you will be destroyed".

B) The cognition of Imam: as the position of Imamate is the highest stage of world and the highest duty of every Muslim is to know Imam. The Holy Prophet said: "Anyone who dies not knowing his Imam has in fact died an ignorant death".

This narrative is famous and quoted in sources of both Great Sects of Islam. The death of someone who does not know his Imam is regarded as the death of ignorance. Of course, the meaning of Imam's cognition is not just knowing the format and superficial aspects such as race and other points, because such things cannot lead to an ignorant death.

All those who stood in front of Imam Hussein in Ashura knew the Imam by race and family very well, they even testified that, but they did not know the real and actual position of Imamate. So, can we say that the killer of Imam Hussein had the knowledge and cognition concerning Imam for knowing his race and family? Absolutely not! So, the meaning of knowledge and cognition mentioned in the Narrative is not just superficial and apparent, but rather that is the knowledge and cognition of Imamate as the supreme stage bestowed by God and belief in Wilayat and compulsory obedience.

So, the cognition of the Imam whose compulsory obedience is ordered by God is the main point and real meaning of this narrative.

One who does not know the real guide and leader of Ummah goes astray and is stuck in darkness. So, Imam Ali introduces the ignorance concerning 
Imam whose obedience is ordered by God as the least thing of going astray and getting stuck in darkness (Majlisi 1983: LXVI/16).

Imam Sadiq said: "Anyone who dies while he does not know his Imam, dies with ignorance." Then he said "you must obey him, and... all dignities are for us and we are those whose obedience is ordered by God."

When anyone knows this compulsory obedience Imam and perceives His high level of Imam and regards His obedience as the obedience of the Holy Prophet whose obedience is the same as the obedience of God "Whoever obeys the Apostle certainly obeys Allah" (4: 80). Such a person will not lose the target but rather they can grasp heavenly sciences willingly with open eyes and perspicacious heart while obeying his Imam.

With pondering on the former Narratives, "a deep relationship between Unitary or Monotheism (Tawhidi) cognition and Imamate and its significance of human guidance and salvation (happiness/sa'adat)" has been explained well. Thus, according to the Shia belief, the cognition and obedience of Wilayat of Imam of every era separates human being from ignorant culture.

\section{Muslims Research Scholars' and Philosophers' Argument on the Significance of Imam's Existence}

In this part, we point out the viewpoint of some Islamic scholars about the significance of Imam's existence.

1. Mulla Mehdi Narraqi says: Imamate is one of fundamental roots of religion and this point is so clear. Because the survival of religion depends on the Imam's existence, so,if there had been no Imams after the Holy Prophet, the religion would not survive. So, such thing is one of the fundamental roots of religion.

2. Majlisi says in Bihar al-Anwar: It should be known that all Imamia scholars have consensus that the validity and acceptability of actions are conditioned with belief. One of its pillars is the confession of Wilayat and Imamate of Infallible Figures as the narratives on this point is near to Tawatur among Shia and Sunni (Majlisi 1983).

So, it can be concluded that Imamate and Wilayat is a door which is opened by God for His own worshipping and His servants' guidance is regarded possible only through this way and stream. i.e. Imams are the door of Divine guidance for us.

3. Hakeem Sabzawari says: The cognition of Imam and knowledge of Imamate are one of the fundamental religious pillars and certainties. The cognition of Imam is the stage of the Prophet's cognition and the cognition of Prophet is the stage of the cognition of God. 
4. Ibn Khaldun says in his Prolegomena: Shia regards Imamate as the pillar of religion and the root of Islam. They do not let it be neglected and they are handed over to Ummah by Prophet, but it is compulsory to determine an Imam for Ummah who is without any minor and major sins.

Therefore, the Imamate has a significant and important position in Shiite.

\section{The Pillars of Nearness (Qurb)}

The formerly mentioned Qurb has some pillars, and in case such pillars did not exist, there would be no Qurb. The pillars are the following:

1. Destination or target

2. An Approaching object

3. Distance

The target is the position which is distanced from an approaching object while the distance means a thing by which the nearness or farness and distance is measured. God is the target in this research and the instances of an approaching object are Divine servants and seekers of Allah while the spiritual stages are distances.

So, those who have grasped higher spiritual stages are nearer to God and those who have not are far from the Divine blessing and grace.

\section{Belief in God}

The first step for the pavers of the Divine way is the belief in God i.e. having certain cognition of surrender and humiliation. Thus, if someone does not have the cognition of God, he will lose the first step of Qurb, which is granted by the primary cognition in the frame of belief.

Imam Ali said in the Sermon 110 of Nahj al-Balaghah: "The best means by which seekers of nearness to Allah, the Glorified, the Exalted, seek nearness, is the belief in Him and His Prophet".

Because the main root of positive and constructive movements is belief. In other words, the root and base of all goodness is belief, as without belief, no movement towards Divine compulsories and religious duties would happen. Because belief in God persuades Divine compulsories and belief in resurrection restrains a man from the divinely prohibited ones.

The school of supplication and Dua teach us that the prerequisite of getting Divine Qurb and reaching perfection is entering the world of belief. 
However, anyone who performs all good things and passes his day and night in serving people, but does not believe in God, loses the stage of Divine Qurb, because he/she does not have the direction of heart and spirit toward above and toward the absolute perfection.

According to Dua Abu Hamza Thomali, one of the obstacles in the war of memorizing God and losing Tawfiq of Divine worship and speak with God is disbelief and distrust of God. "Perhaps, You have found me in the manner of the liars and thus You have rejected me, or, perhaps, You have observed me showing no gratitude for Your graces and thus You have deprived me of them."

So, disbelief in God and denying Divine promises restrain a human-being from the journey toward Allah and from ascending the stage and position of Qurb and perfection. Thus, Imam Zain al-Abidin wishes from God to bestow the highest level of belief. "O God, bless Muhammad and his Household, cause my faith to reach the most perfect faith, make my certainty the most excellent certainty" (Sahifa Sajjadiyya 2010).

\section{Bending on Divine Tawfiq (Help and Assistance)}

Tawfiq (Help and Assistance) is a state which is bestowed by Allah and through which we will successfully achieve belief and adopt all characters and movements with pure culture of God (Ansarian 2007: II/489).

The achievement of Divine Qurb and reaching the nearness of Almighty God is a Tawfiq which is bestowed by His Mercifulness as if He does not like or will it, there will be nothing. So, we have endeavoured in this war and requested humbly from God to bless Tawfiq upon us as done by our Infallible Figures in their supplications:

- $\quad$ as we read in Namaz Jafar Tayyar: "O My God, I request from You the Tawfiq of guided people and characters of pious ones" (Majlisi 1983: XCI/198).

- as mentioned in the Dua of $13^{\text {th }}$ day of Ramazan: "O My God, grant me success in it for righteousness and for the company of the kind ones with Your assistance."

- $\quad$ as in the Dua of $22^{\text {nd }}$ night of Ramazan: "And bestow me the Tawfiq with which Your Excellency has blessed the Shia of Mohammad Household [Al-i Muhammad]" (ibid.: XCVIII/53). "And I ask You through Your munificence to bring me near to Your proximity, and to provide me with gratitude toward You, and to inspire me with Your remembrance" (ibid.). 
Amir al-Mumineen requests three stages of the most valuable stages of seekers of Allah in these heavenly and sublime sentences:

1. Achieving the stage of Qurb;

2. Reaching the stage of Gratitude;

3. Reaching the stage of Remembrance.

Without doubt, acquiring these three stages is impossible without the blessing and generosity of God. Because, if He does not bless zeal and delight and carry the bases for reaching such stages, no one can reach such sublime spiritual stages and steps. For this reason, the seeker wants blessing and generosity as the instrument and capital for becoming able to acquire the above-mentioned stages in the shadow of these two characters.

In another phrase of this Dua, Imam says: "And make me one of the most excellent of Your slaves in Portion from You, And the nearest of them in station to You, And the most elected of them in proximity to You. For that cannot be attained except by Your bounty" (ibid.).

So, in order to reach the supreme spiritual stage, along with the will and decision, a human-being needs Tawfiq. Tawfiq is a bounty of God. Tawfiq will make this dangerous journey easy and feasible. This point is one of the important doctrines of Sahifa Sajjadiyya, when Imam says: "O He whose eyes fall short of seeing! Bless Muhammad and his Household and bring us close to Thy nearness!" (Sahifa Sajjadiyya 2010: Supplication 5)

And, he also says: "O God, bless Muhammad and his Household and point me straight to resist him who is dishonest toward me with good counsel, repay him who separates from me with gentle devotion, reward him who deprives me with free giving, recompense him who cuts me off with joining, oppose him who slanders me with excellent mention, give thanks for good, and shut my eyes to evil!" (ibid.: Supplication 20)

\section{Tawakkul (Trust); Provisions for the Proximity}

Imam Sajjad introduced Tawakkul as the Provisions for the Seekers in the way of Allah as following: "O! My God, even though my provisions to come close to you are few, my absolute trust in you has given me great expectations about you" (Sahifa Sajjadiyya 2010: The 15 Whispered Prayers of As-Sahifa al-Kamila as-Sajjadiyya, The Whispered Prayer of the Beseechers).

Tawakkul is taken from "wakala" and "wakalah" which means trust someone and make him deputy or proxy (Raghib Isfahani 1992: 531). 
In Islamic culture and Sahifa Sajjadiyya, the same as its literal meaning, it means that human-beings trust God as a reliable support (Ansari 2006: 33; Misbah Yazdi 1996: 14).

As this meaning is mentioned in several supplications of Sahifa Sajjadiyya, e.g.: "O God,... cut off my need for this world, make my desire for what is with Thee become a yearning to meet Thee, and give me true confidence in Thee!" (Sahifa Sajjadiyya 2010: Supplication 54).

Along with requesting to cut his need to the mortal world, Imam requests sincerity in Tawakkul and trust in God as Imam says in other phrases: "In all of this, place me through my asking Thee among those who set things right, those who are answered favourably when they request from Thee and from whom is not withheld when they put their trust in Thee" (ibid.: Supplication 25).

"Wilt Thou free from need him who complains to Thee of his indigent need with confidence?" (ibid.: Supplication 16).

"Thou hearest him who complains to Thee! Thou receivest him who has confidence in Thee!" (ibid.: Supplication 51).

Imam Sajjad points out in these phrases that a human-being is dependent and needy as he cannot arrange his own needs and needs of others to help. Other persons either don't help at all or, in case of their help, he should pay thanks even if their assistance is somehow insufficient. For this reason, Imam Sajjad calls human-beings to call Allah who is Omnipotent, and his blessing and mercies are unlimited:

"O God, I have no endurance for effort, no patience in affliction, no strength to bear poverty. So, forbid me not my provision and entrust me not to Thy creatures, but take care of my need alone and Thyself attend to sufficing me! Look upon me and look after me in all my affairs, for if Thou entrustest me to myself, I will be incapable before myself and fail to undertake that in which my best interest lies. If Thou entrustest me to Thy creatures, they will frown upon me, and if Thou makest me resort to my kinsfolk, they will refuse to give to me; if they give, they will give little and in bad temper, making me feel long obliged and blaming me much" (ibid.: Supplication 22).

On the bases of the mentioned discussion, it can be said that the educational and pedagogic system of Sahifa Sajjadiyya is based on Tawakkul and trust in God as this one should be regarded as the main rule of pedagogic 
programs. "And whoever puts his trust in Allah, He will suffice him" (65:3).

The call of the Quran was so forever: "and in Allah let all the faithful put their trust" (3: 122).

The faithful persons should trust God only, no others. Why so? We saw that no one has any facility and blessing on their own. All things are from God. Whenever He wants, He will retake. For this reason, all people are poor towards His Almighty and He is rich per se. Even their existence is for God. "O mankind! You are the ones who stand in need of Allah, and Allah - He is the All-sufficient, the All-laudable. If He wishes, He will take you away, and bring about a new creation; and that is not a hard thing for Allah" (35: 15-17).

This viewpoint concerning God will bring human approach toward the Creator only and he will trust no other creature. This comprehension is spread throughout the $28^{\text {th }}$ Supplication of Sahifa Sajjadiyya. This valuable supplication is composed of sentiment and argument as it presents the meaning of servitude in a precise and efficient way, like the fundamental structure of a system. Thus, Imam Sajjad requests sincerity in Tawakkul and certainty of believers in God Himself.

\section{Breaking Hope of Other than God as the Secret of the Divine Qurb}

At the first step, when people look at ourselves and other entities, they regard that those things are independent and do not need anything other than themselves, even their needs are superficial. When human-beings' theoretical and intellectual power has gradually become perfect, they understand that entities are creatures of a powerful and wise existence. At the upper step, they are brought to the Divine cognition and veils of doubt and illusion are put down and they understand that Allah is the only unlimited power and eternal existence.

This point is clearly pointed out in Infallible Figures' supplications, particularly in Dua'a Abu Hamza Thomali as following:

"All praise be to Allah alone for other than Whom I do not hope And even if I hope for anyone else, he shall certainly disappoint me All praise be to Allah alone Who has accepted me to depend upon Him and, thus, bestowed favours upon me He has not left me to the people who will thus definitely humiliate me All praise be to Allah alone Who has sought my friendship while $\mathrm{He}$ can dispense with me (All) praise be to Allah (alone) Who showed Himself gentle and considerate towards me as if I have not sinned, Accordingly, my Lord is the only One Whom I should thank and He is the worthiest of being thanked by me" (Qommi 2002: Du'a Abu Hamza Thomali). 
How wonderfully Imams request God we can read in The Invocation (Munajat) Shabaniyah:

"O my God, (please) grant me absolute devotion to You, and illuminate the sights of our hearts with the light of observing of You, so that the sights of the hearts will penetrate the Screens of Light, and arrive at the Core of Magnificence, and that our souls hang to the majesty of Your Holiness" (ibid.: Munajat Shabaniyah).

One of the messages of this Dua of Imam is that only by cutting off from all others can someone become near to God. So, the seeker should be independent towards all others apart from God, as we can read in the following Dua:

"O God, I showed sincerity by cutting myself off from everything but Thee. I approached Thee with my whole self. I averted my face from everyone who needs Thy support. I ceased to ask from any who cannot do without Thy bounty. I saw that the needy who seeks from the needy is foolish in his opinion and misguided in his intellect" (Sahifa Sajjadiyya 2010: Supplication 28).

Generally, everything that restrains us from human independence, egoism and polytheism can lead us toward Divine Qurb, for arranging such ground is the baseline of putting down the veils between God and His slave. When this situation occurs, a human-being knows their own existential relationship with God. Otherwise, if they do not know, how can they acquire Qurb?

\section{Fear and Hope}

Fear and Hope (Khawf wa Raja') are two of the very important characteristics of human-beings and doctrines of Sahifa Sajjadiyya. These two characteristics exist in everyone regardless of religion, race, gender and nation. Because from the childhood, everyone perceives fear and hope as these become a part of his intimate and innate. The seeker in the way of Allah paves his journey of Qurb with provision of fear and hope.

For explaining this point, we analyse these two concepts and then clarify the stand of Sahifa Sajjadiyya:

\section{A. Fear (Khawf)}

This word has been used in the meaning of fear, dread, horror, concern, and being anxious (Ibn Manzur 1997; Dehkhoda 1994: XI/590). It is inter- 
esting that on the basis of its literal meaning, this word signifies the state and situation of "fear" in religious terms which arises from the Tawhidi (Unitary and Monotheism) perspective of Islam. Because God can deprive us in future of all our blessings both of this world and hereafter (Makarim Shirazi 2006: 385). Imam Sajjad has pointed out this fact in several supplications. It is the innate knowledge of human-beings which is pointed out in Sahifa Sajjadiyya that God can deprive us from this world blessings like life, health, friends, acquaintances, children, property, etc. We have to understand well that God can make human-beings deprived of paradise and its blessings, and particularly, He can make us far from Him and His mercy (ibid.).

We said that a religion has the key role in explaining the real object of fear and hope. All religions, specially Islam, regard "fear from God" as the most important advantage of believers and the state of fear of Ummah leaders (ibid.: 211).

Imam Sajjad has pointed out this issue several times in Sahifa Sajjadiyya and, in most of them, the object of fear is God.

\section{Fear of God:}

“Thee I fear, from Thee I seek aid” (Sahifa Sajjadiyya 2010: Supplication 52).

"Thou hast seen, my God, the flow of my tears in fear of Thee" (ibid.: Supplication 16).

2. Fear from the stage of God:

"Fill me with fear of Thy station, make me yearn for the meeting with Thee" (ibid.: Supplication 47).

3. Fear from meeting God:

"I have approached the terror of meeting Thee" (ibid.: Supplication 21).

4. Fear from punishment:

"O God, provide us with fear of the threatened punishment" (ibid.: Supplication 45).

In Sahifa Sajjadiyya, there are a lot of Supplications like $8^{\text {th }}$ (Seeking Refuge), $10^{\text {th }}$ (Seeking Asylum with God), $12^{\text {th }}$ (Confession), $16^{\text {th }}$ (Asking Release), 
$28^{\text {th }}$ (Fleeing to God) and $31^{\text {st }}$ (Repentance) which talk about fear and hope as a means of reforming behaviours.

So, fear is another characteristic of human-beings which has effective role in reforming human characters. Because, if fear was not in human hearts, then ignorance and pride would motivate a human-being to rebel, which leads to his own decay and destruction.

\section{B. Hope (Raja')}

The word "Raja" is used against "Khawf" and it means expectation and wish (Raghib Isfahani 1992). From Islamic viewpoint, "hope" is aroused from the cognition of God, for God can continue this world blessings and can increase in quantity and quality and can bestow us with great rewards in Hereafter.

We believe that God is the real effective in the world. Therefore, all things should depend on Him. In Sahifa Sajjadiyya, the object of "Hope" is God; "Hope" is regarded as one of the manifestations of Monotheism. This holy book considers "Hope" towards God as one of the most favoured characteristics of a believer in God. Namely, he should have hope of God, no one else.

There is no expectation of the Seeker of the Qurb except for the Divine mercy, as "His mercy is more than punishment and His happiness is more than anger" (Sahifa Sajjadiyya 2010: Supplication 14); “Thou art He whose bestowal is greater than His withholding! Thou art He by whose mercy all creatures are embraced!" (ibid.: Supplication 16); “O He who shows gratitude for the small and rewards with the great! $\mathrm{O} H e$ who comes close to him who comes close to Him! O He who invites to Himself him who turns his back on Him! O He who changes not favour and rushes not to vengeance!" (ibid.: Supplication 46)

All supplications of Sahifa Sajjadiyya have such contents that a human-being does not lose his hope of Divine mercy, like the Supplications: "Confession", "Repentance" and "Asking Release". Some of them are mentioned here:

1. Expectation of God:

"And I hope for no one other than Thee" (ibid.: Supplication 46).

2. Expectation of Divine Mercy:

"I only scold my own soul" (ibid.: Supplication 46). 
"My God, I have no mediation with Thee but the tender acts of Thy clemency, nor any way to come to Thee but the gentle favours of Thy mercy" (Majlisi 1983: XCI/148).

\section{Expectation of Divine Forgiveness:}

"So he went ahead with it knowing Thy threat, hoping for Thy pardon, and relying upon Thy forbearance" (Sahifa Sajjadiyya 2010: Supplication 47).

4. Expectation of the Prophet and His Progeny's Intercession:

"Nor in the intercession of any creature in whom I have hope, except the intercession of Muhammad and the Folk of his House (upon him and upon them be Thy peace)" (ibid.: Supplication 48).

\section{Expectation of Happiness and Fortune}

"Hoping for a commerce that comes not to naught" (Quran 35: 29; Sahifa Sajjadiyya 2010: Supplication 4).

So, "Fear" and "Hope" are essential and necessary traits of a Seeker Human-being, since, if any one of them does not exist, a deficiency will happen in the Human and his psychological traits, and this will have a bad influence on human behaviour and his happiness and spirituality.

Another point that should be noted is that the role of "Fear" and "Hope" is the balancing measure of human life as a human-being cannot continue living without any of them and such a man will be led to absurdity and nihilism.

On the other hand, if a human-being forgets "Fear", he will develop negligence and arrogance and will be led to his own rebellion and destruction. So, the levels of "Fear" and "Hope" should be in balance. Imam Sajjad pointed out to such balance in his supplication as:

"Fill me with fear of Thy station, make me yearn for the meeting with Thee" (ibid.: Supplication 47).

It is necessary to point out that the expectation of the Divine comprehensive grace is not such a way that the Seeker would give importance to His orders or shorten them for His grace, but rather the Seeker should perform all Divine orders and laws as best as possible and not think that his own 
practice is enough. Because his practicing Divine laws is only like of a drop of water in front of the ocean of Divine grace as we can read in Munajat Shabaniyah:

"O my God, if my deed is too little when compared to the true obedience to You, then my hope for You is too big when compared to my prospect from You" (Qommi 2002).

\section{Conclusion}

From the viewpoint of Infallible Figures, human-beings, having accurate perception and the certain belief in God, using factors and instruments like monotheism and Tawakkul (trust), and the consideration of His mercy and pleasure, and practicing the factors like Zikr (remembrance), praising and thanking God, with repentance, supplication and innovation, and removing the obstacles like ignorance, polytheism, paganism, doubt concerning religion and Divine laws, negligence, material world loving and fleeing from Satanic trap, can reach Qurb of Allah. In this research, Sahifa Sajjadiyya, the book of Imam Sajjad, was explicitly mentioned in order to investigate the epistemic principles of Qurb of Allah. In this study, in order to reach Qurb of Allah, some pillars are extracted from Sahifa Sajjadiyya, namely: faith, an attempt to obtain Tawfiq (assistance), Tawak$k u l$ (trust), cutting off all things other than God, cognition and living with fear and hope. According to the current research, the mentioned pillars are regarded as the most important and fundamental epistemic bases and foundations for reaching Qurb (nearness and proximity) in the supplications of Imam Sajjad's Sahifa Sajjadiyya.

Received: June $6^{\text {th }}, 2019$.

Accepted: November 15 ${ }^{\text {th }}, 2019$.

\section{Bibliography}

Holy Quran.

Ansari, Abduallah (2006), Manazil al-Sa'irin, Qom, Bidar Publications.

Ansarian, Hossein (2007), Islamic Mysticism; Commentary on Misbah al-Shariah, Qom, Dar al-Irfan Publications.

Dehkhoda, Ali Akbar (1994), Loghat Nameh, Tehran, Tehran University Press.

Ibn Manzur, Jamal al-Din (1997), Lisan al-Arab, $1^{\text {st }}$ Edition, Beirut, Dar al-Sadir. 
Majlisi, Muhammad Baqir (1983), Bihar al-Anwar, $2^{\text {nd }}$ Edition, Beirut, Dar al-Wafa.

Makarim Shirazi, Nasir (2006), Morals in Quran, Qom, Madrasah Imam Amir al-Muminin.

Misbah Yazdi, Muhammad Taqi (1996), Rahiyan-e Kuye Dust, Qom, Imam Khomeini Educational and Research Institute.

Nahj al-Balaghah (2003), Tehran, Zuhd.

Qommi, Abbas (2002), Kulliyat of Mafatih al-Jinan, Qom, Tahzib Publications.

Raghib Isfahani, Hossein bin Muhammad (1992), al-Mufradat fi Gharib al-Quran, Beirut, Dar al-Ilm.

Zayn al-Abidin, Imam Sajjad (2010), Sahifa Sajjadiyya, Qom, Dar al-Nur Publications. 